\title{
GENETIC DIVERSITY OF MAIZE ACCESSIONS (ZEA MAYS L.) CULTIVATED FROM EUROPE USING MICROSATELLITES MARKERS
}

\author{
Vivodík Martin*, Petrovičová Lenka, Balážová Želmíra, Gálová Zdenka
}

Slovak University of Agriculture in Nitra, Faculty of Biotechnology and Food Sciences, Department of Biochemistry and Biotechnology

\begin{abstract}
Maize (Zea mays L.) or corn is a plant belonging to the family Poaceae and is one of the most important cereal crops worldwide as human nutrient, a basic element of animal feed and raw material for manufacture of many industrial products. Maize is the oldest plant to have a fully established gene map with the basic genome consisting of 10 chromosomes and is an excellent plant for the detection of genotoxins, mutagenic and clastogenic substances in the environment. The SSR molecular markers were used to assess genetic diversity in 20 old European maize genotypes. Five SSR primers revealed a total of 33 alleles ranging from 5 (UMC1962) to 8 (UMC1370) alleles per locus with a mean value of 6.60 alleles per locus. Variations in DNA sequences lead to polymorphism. Greater polymorphism is indicative of greater genetic diversity. The PIC values ranged from 0.780 (UMC1962) to 0.842 (UMC1370) with an average value of 0.814 and the DI value ranged from 0.794 (UMC1962) to 0.848 (UMC1370) with an average value of 0.823 . $100 \%$ of used SSR markers had PIC and DI values higher than 0.7 that means high polymorphism of chosen markers used for analysis. Probability of identity (PI) was low ranged from 0.005 (UMC1241 and UMC1370) to 0.011 (UMC1859) with an average of 0.007. A dendrogram based on UPGMA analysis separated 20 maize genotypes into two clusters. First cluster contained two maize genotypes Bučiansky Konský Zub (SK) and Moldavskaja (SUN). Cluster two was divided into two main cluster 2a and 2b. SSR markers are useful in the assessment of maize diversity, the detection of duplicate sample in genotypes collection, and the selection of a core collection to enhance the efficiency of genotypes management for use in maize breeding and conservation.
\end{abstract}

Keywords: old maize; genetic diversity; SSR markers; dendrogram; PIC

\section{Introduction}

With the advent of the first maize hybrids, in 1933 in the US and around 1950 in Europe, maize cultivation has undergone a complete change. Numerous open-pollinated landraces adapted to specific regions were substituted by a limited number of hybrids bred from a large genetic basis (Gay, 1984). Today, the main maize hybrids cultivated in the world involve a restricted number of key inbred lines. Therefore, genetic diversity of those cultivars is almost certainly limited, in comparison to the large genetic diversity available in genebanks (Gay, 1984). A few years ago, the threat of genetic erosion led to a significant interest in the assessment of genetic diversity in germplasm collections and a huge number of studies on various crops (Dubreuil and Charcosset, 1998).

*Corresponding author: Martin Vivodík, Slovak University of Agriculture in Nitra, Faculty of Biotechnology and Food Sciences, Department of Biochemistry and Biotechnology, $\square$ vivodikmartin@gmail.com 
Molecular markers based on polymerase chain reaction (PCR) methods, such as simple sequence repeats (SSRs) or microsatellites, have become important genetic markers in a wide range of crop species, including maize (Elçi and Hançer, 2015).

SSRs markers have many advantages over other types of molecular markers, such as co-dominance, abundant in genomes, highly polymorphisms, locus specificity, good reproducibility and random distribution throughout the genome (Sun et al., 2011). These features, coupled with their ease of detection, make them ideal for identifying and distinguishing between accessions that are genetically very similar (Saker et al., 2005).

For the analysis of genetic diversity of maize genotypes were used several dominant molecular markers: amplified fragment length polymorphism (AFLP) (Roy and Kim, 2016), random amplified polymorphic DNA (RAPD) (Balážová et al., 2016), start codon targeted (SCoT) (Vivodík et al., 2016), inter-simple sequence repeat (ISSR) (Idris et al., 2012; Žiarovská et al., 2013) and sequence-related amplified polymorphism (SRAP) (Abd El-Azeem et al., 2015). And codominant molecular markers were also used for the analysis of maize genotypes: simple sequence repeat (SSR) (Shiri et al., 2014), expressed sequence tag (EST)-SSR (Galvão et al., 2015), single nucleotide polymorphism (SNP) (Sa et al., 2012) and using protein markers (SDS-PAGE) (Vivodík et al., 2016). Suitability of SSR markers for the construction of genetic maps, fingerprinting and phylogenetic studies has been proved by many authors in many crops, such as castor (Gálová et al., 2015), rye (Balážová et al., 2015), wheat (Han et al., 2015), barley (Maniruzzaman et al., 2014), triticale (Vyhnánek et al., 2009), maize (Salami et al., 2016) and many other crops.

The present study aimed to examine the genetic variability within and among old maize genotypes cultivated in the Europe, using 5 SSR markers. The data collected will contribute to identification, rational exploitation and conservation of germplasms of maize genotypes.

\section{Materials and methodology}

Maize genotypes (20) were obtained from the Gene Bank VURV Praha-Ruzine (Czech Republic) and from the Gene Bank in Pieštany, the Slovak Republic. DNA of 20 genotypes of maize was extracted from leaves of 10 day old seedlings using the Gene JET Plant Genomic DNA Purification Mini Kit. Maize genotypes were grown in a growth chamber on humus soil.

\section{SSR analysis}

Amplification of SSR fragments was performed according to (Elçi and Hançer, 2015). Polymerase chain reaction (PCR) were performed in $20 \mu \mathrm{l}$ of a mixture containing $7.5 \mu \mathrm{l} \mathrm{H} \mathrm{O}_{2}, 10.0 \mu \mathrm{l}$ Master Mix (Genei, Bangalore, India), $0.75 \mu$ l of each primer (10 pmol) and $1 \mu$ DNA (100 ng). Amplification was performed in a programmed thermocycler (Biometra, Germany) and amplification program consisted of an initial denaturing step at $94^{\circ} \mathrm{C}$ for $2 \mathrm{~min}$, followed by 35 cycles of amplification $\left[95^{\circ} \mathrm{C}(30 \mathrm{~s})\right.$, $1 \mathrm{~min}$ at the $\left.55^{\circ} \mathrm{C}, 72{ }^{\circ} \mathrm{C}(30 \mathrm{~s})\right]$ and a final elongation step at $72^{\circ} \mathrm{C}$ for $10 \mathrm{~min}$. Amplification products were confirmed by electrophoresis in $7 \%$ denaturing polyacrylamide gels and silver stained and documented using gel documentation system Grab-It 1D for Windows.

\section{Data analysis}

For the assessment of the polymorphism between castor genotypes and usability of SSR markers in their differentiation diversity index (DI) (Weir, 1990), the probability of identity (PI) (Paetkau et al., 1995) and polymorphic information content (PIC) (Weber, 1990) were used. 


\section{Results and discussion}

Five maize SSR primers were used for identification and estimation of the genetic relations among 20 old European maize genotypes. All 5 SSR primers generated clear banding patterns with high polymorphism. Five SSR primers revealed a total of 33 alleles ranging from 5 (UMC1962) to 8(UMC1370) alleles per locus with a mean value of 6.60 alleles per locus (Table 1). Variations in DNA sequences lead to polymorphism. Greater polymorphism is indicative of greater genetic diversity. The PIC values ranged from 0.780 (UMC1962) to 0.842 (UMC1370) with an average value of 0.814 and the DI value ranged from 0.794 (UMC1962) to 0.848 (UMC1370) with an average value of 0.823 (Table 1). $100 \%$ of used SSR markers had PIC and DI values higher than 0.7 that means high polymorphism of chosen markers used for analysis. Probability of identity (PI) was low ranged from 0.005 (UMC1241 and UMC1370) to 0.011 (UMC1859) with an average of 0.007 (Table 1). A dendrogram based on UPGMA analysis separated 20 maize genotypes into two clusters (Figure 1). First cluster contained two maize genotypes Bučiansky Konský Zub (SK) and Moldavskaja (SUN). Cluster two was divided into two main cluster $2 \mathrm{a}$ and $2 \mathrm{~b}$.

Table 1 List of SSR primers, total number of bands and the statistical characteristics of the SSR markers used in maize

\begin{tabular}{|l|c|c|c|c|}
\hline Marker name & Number of alleles & DI & PIC & PI \\
\hline UMC1859 & 7 & 0.808 & 0.799 & 0.011 \\
\hline UMC1241 & 6 & 0.830 & 0.823 & 0.005 \\
\hline UMC1370 & 8 & 0.848 & 0.842 & 0.005 \\
\hline UMC1962 & 5 & 0.794 & 0.780 & 0.010 \\
\hline UMC1380 & 7 & 0.835 & 0.827 & 0.006 \\
\hline Average & 6.60 & 0.823 & 0.814 & 0.007 \\
\hline
\end{tabular}

$\mathrm{DI}$ - diversity index; PIC - polymorphic information content; PI - probability of identity

Main cluster 2a contained genotype Dnepropetrovskaja (SUN) and main cluster 2b was divided into two subclustrov $2 \mathrm{ba}$ and $2 \mathrm{bb}$. Subcluster $2 \mathrm{ba}$ contained three genotypes- Iregszemeseil 2 hetes (HUN), Aranyozon sarga lofogu (HUN) and Mikulická (CZE) and subcluster 2bb contained other 14 genotypes of maize. We could not distinguish two genotypes, M Silokukurica (HUN) and Bezuncukskaja (SUN) (subcluster 2bb), which can be caused due to close genetic background (Figure 1). 
Genotypes

$\begin{array}{ll}\text { M Silokukurica } & \text { HUN } \\ \text { Bezuncukskaja } & \text { SUN } \\ \text { Hod. k. z. žltý } & \text { CZE } \\ \text { Valticka } & \text { CZE } \\ \text { Manalta } & \text { CZE } \\ \text { Celchovicka ADQ } & \text { CZE } \\ \text { Czechnicka } & \text { POL } \\ \text { Wielkopolanka } & \text { POL } \\ \text { Toschevska } & \text { SK } \\ \text { Zlota gorecka } & \text { POL } \\ \text { Belaja mestnaja } & \text { SUN } \\ \text { Šamorin. k. zub } & \text { HUN } \\ \text { Przebedo. Biala } & \text { POL } \\ \text { Bučanská žltá } & \text { SK } \\ \text { Iregszeme. 2 h. } & \text { HUN } \\ \text { Arany. s. lof. } & \text { HUN } \\ \text { Mikulická } & \text { CZE } \\ \text { Dnepropetrovsk. SUN } \\ \text { Moldavskaja } & \text { SUN } \\ \text { Bučiansky K.Zub SK } & \text { SK }\end{array}$

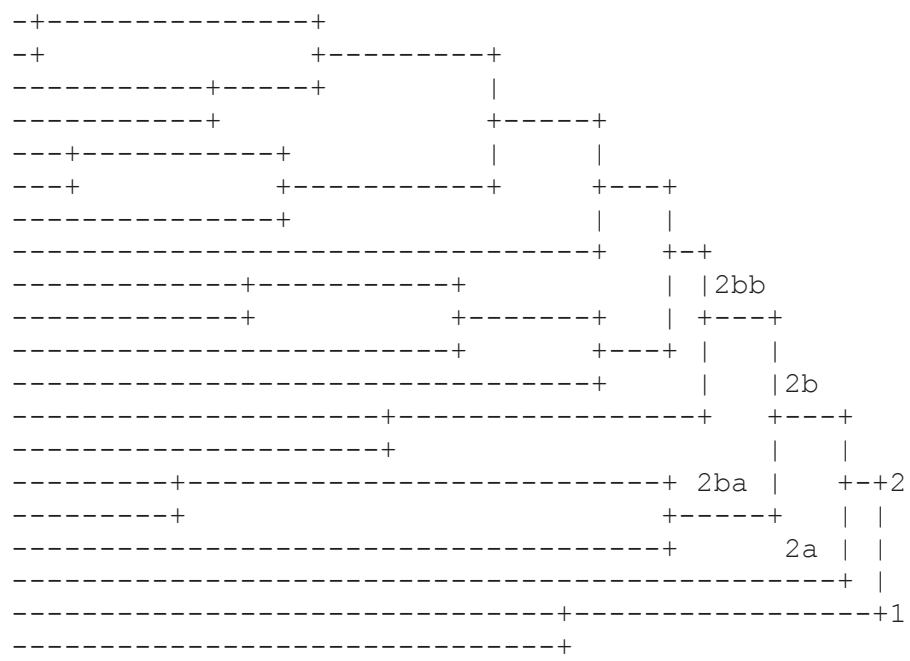

Figure 1 Dendrogram of 20 old maize genotypes prepared based on 5 SSR markers

CZE - Czechoslovakia, HUN - Hungary, POL - Poland, SUN - Union of Soviet Socialist Republics, SK - Slovakia

\section{Conclusions}

In conclusion, a high level of genetic diversity exists among the old maize accessions analyzed. According to analysis, the collection of 20 diverse accessions of maize was clustered into two clusters. First cluster contained two maize genotypes Bučiansky Konský Zub (SK) and Moldavskaja (SUN). Cluster two was divided into two main cluster 2a and 2b. Main cluster 2a contained genotype Dnepropetrovskaja (SUN) and main cluster $2 \mathrm{~b}$ was divided into two subclustrov $2 \mathrm{ba}$ and $2 \mathrm{bb}$. Subcluster 2ba contained three genotypes- Iregszemeseil 2 hetes (HUN), Aranyozon sarga lofogu (HUN) and Mikulická (CZE) and subcluster 2bb contained other 14 genotypes of maize. We could not distinguish two genotypes, M Silokukurica (HUN) and Bezuncukskaja (SUN) (subcluster 2bb), which can be caused due to close genetic background. A SSR marker system is a rapid and reliable method for cultivar identification that might also be used in quality control in certified seed production programs, to identify sources of seed contamination, and to maintain pure germplasm collections.

\section{Acknowledgments}

This work was funded by European Community under project ITMS 26220220180: Building Research Centre "AgroBioTech" (50\%) and KEGA project No 021SPU-4/2015 (50\%).

\section{References}

Abd El-Azeem, R.M., Hashem, M.H., Abd-El-Haleem, S.H.M. 2015. Detection of genetic variability in Zea mays inbred lines using SSRs and SRAP markers. Egypt. J. Genet. Cytol., vol. 44, p. 291-307.

Balážová, Ž., Petrovičová, L., Gálová, Z., Vivodík, M. 2015. Molecular characterization of rye cultivars. Potravinarstvo, vol. 9, no. 1, p. 54-58. http://dx.doi.org/10.5219/522

Balážová, Ž., Vivodík, M., Gálová, Z. 2016. Evaluation of molecular diversity of central European maize cultivars. Emirates Journal of Food and Agriculture, vol. 28, no. 2, p. 93-98. http://dx.doi.org/10.9755/ ejfa.2015-05-204 
Dubreuil, P., Charcosset, A. 1998. Genetic diversity within and among maize populations: a comparison between isozyme and nuclear RFLP loci. Theor Appl Genet., vol. 96, p. 577-587.

Elçi, E., Hançer, T. 2015. Genetic analysis of maize (Zea mays L.) hybrids using microsatellite markers. Tarim Bilimleri Dergisi - Journal of Agricultural Sciences, vol. 21, p. 192-198.

Galvão, K.S., Ramos, H.C., Santos, P.H., Entringer, G.C., Vettorazzi, J.C., Pereira, M.G. 2015. Functional molecular markers (EST-SSR) in the full-sib reciprocal recurrent selection program of maize (Zea mays L.). Genet Mol Res., vol. 14, no. 3, p. 7344-7355. http://dx.doi.org/10.4238/2015.july.3.10

Gay J.P. 1984. Fabuleux mais - Histoire et avenir d'une plante. AGPM, Pau, p. 295.

Gálová, Z., Vivodík, M., Balážová, Ž., Kutkka Hlozáková, T. 2015. Identification and differentiation of Ricinus communis L. using SSR markers. Potravinarstvo, vol. 9, no. 1, p. 556-561. http://dx.doi.org/10.5219/516

Han, B., Wang, C., Tang, Z., Ren, Y., Li, Y., Zhang, D., et al. 2015. Genome-Wide Analysis of Microsatellite Markers Based on Sequenced Database in Chinese Spring Wheat (Triticum aestivum L.). PLoS ONE, vol. 10, no. 11, e0141540. http://dx.doi.org/10.1371/journal.pone.0141540

Idris, A.E., Hamza, N.B., Yagoub, S.O., Ibrahim, A.I.A., El-Amin, H.K.A. 2012. Maize (Zea mays L.) genotypes diversity study by utilization of Inter-Simple Sequence Repeat (ISSR) Markers. Australian Journal of Basic and Applied Sciences, vol. 6, no. 10, p. 42-47.

Maniruzzaman, A., Talukder, Z.A., Rohman, S., Begum, F., Amiruzzaman, M. 2014. Polymorphism study in barley (Hordeum vulgare) genotypes using microsatellite (SSR) markers. Bangladesh J. Agril. Res., vol. 39, no. 1, p. 33-45.

Paetkau, D., Calvert, W., Stirling, I., Strobeck, C. 1995. Microsatellite analysis of population structure in Canadian polar bears. Mol. Ecol., vol. 4, p. 347-354.

Roy, N.S., Kim, N.S. 2016. Genetic diversity analysis of maize lines using AFLP and TE-based molecular marker systems. Genes Genom, vol. 38, p. 1005-1010. http://dx.doi.org/10.1007/s13258-016-0461-z

Sa, K.J., Park, J.Y., Park, K.C. et al. 2012. Analysis of genetic mapping in a waxy/dent maize RIL population using SSR and SNP markers. Genes Genom, vol. 34, p. 157-164. http://dx.doi.org/10.1007/s13258-011-0208-9

Saker, M., Nagchtigall, M., Kuehne, T.A. 2005. Comparative assessment of DNA fingerprinting by RAPD, SSR and AFLP in genetic analysis of some barley genotypes. Egypt J Genet Cytol, vol. 34, p. 81-97.

Salami, H.A., Sika, K.C., Padonou, W., Aly, D., Yallou, C., Adjanohoun, A., Kotchoni, S., Baba-Moussa, L. 2016. Genetic diversity of maize accessions (Zea mays L.) cultivated from Benin using microsatellites markers. American Journal of Molecular Biology, vol. 6, p. 12-24. http://dx.doi.org/10.4236/ajmb.2016.61002

Shiri, M.R., Choukan, R., Aliyev, R.T. 2014. Study of genetic diversity among maize hybrids using SSR markers and morphological traits under two different irrigation conditions. Crop Breeding Journal, vol. 4, no. 1, p. 65-72.

Sun, D.F., Ren, W.B., Sun, Gl., Peng, J.H. 2011. Molecular diversity and association mapping of quantitative traits in Tibetan wild and worldwide originated barley. Euphytica, vol. 178, p. 31-43. http://dx.doi. org/10.1007/s10681-010-0260-6

Vivodík, M., Gálová, Z., Balážová, Ž., Petrovičová, L. 2016. Start codon targeted (SCoT) polymorphism reveals genetic diversity in European old maize (Zea mays L.) genotypes. Potravinarstvo, vol. 10, no. 1, p. 563-569. http://dx.doi.org/10.5219/660

Vivodík, M., Gálová, Z., Balážová, Ž., Petrovičová, L., Kut'ka Hlozáková, T. 2016. Genetic variation and relationships of old maize genotypes (Zea mays L.) detected using SDS-PAGE. Potravinarstvo, vol. 10, no. 1, p. 532-536. http://dx.doi.org/10.5219/661

Vyhnánek, T., Nevrtalová, E., Slezáková, K. 2009. Detection of the genetic variability of triticale using wheat and rye SSR markers. Cereal Research Communications, vol. 37, no. 1, p. 23-29.

Žiarovská, J., Senková, S., Bežo, M., Ražná, K., Masnica, M., Labajová, M. 2013. ISSR markers as a tool to distinguish Idt and SSS populations of Zea mays L. Journal of Central European Agriculture, vol. 14, no. 2, p. 489-499. http://dx.doi.org/10.5513/jcea01/14.2.1227

Weber, J.L. 1990. Informativeveness of human (dC-dA)n x (dG-dT)n polymorphism. Genomics, vol. 7, p. 524-530.

Weir, B.S. 1990. Genetic data analysis. Methods for discrete population genetic data. 1990 pp. ISBN 0-87893-872-9. 